\title{
Optimum Composition of Developed Additive Based Insect Repellent Paint
}

\author{
Zeeshan Ahmad ( $\nabla$ thearcher93@gmail.com ) \\ Research and Development Head in a company

\section{Faiza Hassan} \\ University of Lahore \\ Sana Noor ( $\nabla$ sananoor949@gmail.com ) \\ University of central Punjab \\ Munir Ahmad ( $\nabla$ munir.ahmad@uclmail.net) \\ Nuclear Medicine Oncology and Radiotherapy Institute \\ Khalid Rashid \\ PCSIR Lahore
}

\section{Research}

Keywords: Optimum Composition, Cymbopogon winterianius, Rosmarinus officinalis, Cedrus, Eugenol

Posted Date: May 24th, 2021

DOI: https://doi.org/10.21203/rs.3.rs-125094/v2

License: (c) (i) This work is licensed under a Creative Commons Attribution 4.0 International License. Read Full License 


\section{Abstract}

Active compounds of Cymbopogon winterianius, Cymbopogoncitratus, Rosmarinus officinalis, Cedrus, and Eugenol, have been reported to have different insect repellant compounds. Control and development of natural insect repellent additive based decorative coating has driven this work to incorporate the essential oils with long chain fatty acids in water-based lab developed conventional paint. In this work, the Additive based Paint was formulated and its ability to repel different insects was determined. The optimum composition of developed additive based paint was determined by three standard paint analyses which were adhesion, elasticity and insect repellency. As per challenge of Pigment powder and Polymer use for such paint is achieved by testing on Latest instruments. The best composition of additive in paint was found to be $15 \%$. Where it able to repel Pavement Ants, non-biting Flies, Mosquitoes and Black field ant with $80 \%$ efficiency. It is envisioned that the formulated paint is effectively function as insect repellent thus as an alternative way to reduce the insect-borne diseases.

\section{Introduction}

Arthropod bites remain a major cause of patient morbidity. These bites can cause local or systemic effects that may be infectious or inflammatory in nature. Arthropods, notably insects and arachnids, are vectors of potentially serious ailments including malaria, West Nile virus, dengue, and Lyme disease[1]. Synthetic organic insecticides used to control insects have produced a feedback of environmental ill effect, non-targets organisms being affected and most mosquito species have becoming physiologically resistant to synthetic insecticides [2]. The application of synthetic repellents may cause allergic to some of people. Higher concentration or frequent application of N, N-diethyl-3-methylbenzamide (DEET) exposure causes insomnia, mood disturbances and impaired cognitive function [3]. While, Plant essential oils have many useful applications beyond those in the fragrance and flavoring industries, among which are their uses as pesticides and insect repellents. An emerging body of scientific literature reports the efficacy of various essential oils for use against pests of public health, stored product pests, and agricultural pests [4]. Generally, EOs cause neurotoxic effects in insects[5].The current study reports the composition and insect repellent activity of a latex coating made by using essential oils fromCitronella (winterianius),Cymbopogon citratus, Rosmarinus officinalis, Lemongrass, Cedrusand Eugenol against several reported insects.

Paint is a liquid which spreads over a substrate in the form of thin layer and it is transformed into a solid adherent film [6]. There are two major functions of paint. One protection and other is decoration. The earliest known use of paints dates back more than 30,000 years to cave paintings in Spain [7].

Differences in the composition of the various coatings systems are presented in Table 1. Common to all three coating systems are the resin and additive[8].

Table 1 Typical composition of various coating systems 


\begin{tabular}{|llll|}
\hline Material Category & Coating Type & & \\
\hline & Pigmented paint & powder coating & Clear coat \\
\hline Resin & yes & yes & Yes \\
\hline Additive & yes & yes & Yes \\
\hline Solvent & yes & no & Yes \\
\hline Pigment \& Extender & yes & yes & No \\
\hline
\end{tabular}

\section{Materials And Method}

\section{Materials:}

Distilled water and all other Paint related chemicals were purchased by Sheikh Traders Lahore,Rutile grade titanium dioxide pigment manufactured by the chloride process for both interior and exterior coatings applications prepared by Ti-Pure is used. Fine powdered $\mathrm{CaCO} 3$ and Talcum was provided by Shaheen Grinding Mills. Other chemicals are as, Thickener from Ashland Chemical Company America, Ammonia solution of Petrokemija from Croatia. Dispersing agent of BASF chemical company is used. two Biocides one for in can preservation named Parmetol DF-35 by Schulke and other one for dry film preservation named Preventol A-14D by LANXESS. Anti-foam for water-based coating developed by Blackburn Chemicals is used Monoethylene glycol (MEG) and UCAR Filmer IBT by DOW Chemicals is used. Acrylic Binder of Code 1229 from Power Chemical Industries is used. Essential Oils were obtained through Attar Oils made by USA. Soya oil is used as long chain fatty acid along with $\mathrm{KOH}$.

\section{Methods:}

\section{KOH salt of Long Chain Fatty Acids:}

Table 2 Composition for Potassium salt of long chain fatty acids

\begin{tabular}{|ll|}
\hline Chemicals & Dosage \\
\hline $\mathrm{KOH}$ & $38 \%$ \\
\hline Long Chain Fatty Acid & $30 \%$ \\
\hline Water & $32 \%$ \\
\hline
\end{tabular}

At first step take water in Glass beaker and add $\mathrm{KOH}$ under proper stirring to make a lye solution. Took Long Chain Fatty Acid in a Glass Beaker and pour Lye solution in it with continuous stirring. Now place the beaker on hot plat to let it boil gently, Keep stirring to avoid spattering of potassium hydroxide solution while using a gentle heat and keep constant stirring. Continue boiling until water evaporates and 
it starts harden. After 30 minutes at $60-70^{\circ} \mathrm{C}$ it become jell type structure then place it at room temperature to cool with constant stirring. After proper mixing cool it and pack it in air tight jar.

\section{Additive Preparation:}

Table 3 Pre mix of Essential Oils

\begin{tabular}{|ll|}
\hline Chemicals & Dosage \\
\hline Citronella Oil & 82.35 \\
\hline Cedar Oil & 5.88 \\
\hline Rosemary Oil & 5.88 \\
\hline Eugenol Oil & 3.52 \\
\hline Lemongrass Oil & 2.35 \\
\hline Total & 100 \\
\hline
\end{tabular}

Citronella oil is one of the most widely used natural insect repellents. So, pre mixture of others Essential oils in Citronella Oil is made up using percentages mentioned in table 3.

Then $30 \%$ Potassium Hydroxide salt of long chain fatty acids is mixed with $70 \%$ of Essential oils premix for finalizing insect Repellent Additive.

\section{Insect Repellent Emulsion:}

Conventional Water based latex emulsion was prepared up as per previously reported method (9). Six different samples were made with different percentages of added additive, and marked as bellow,

Table 4 Sample Coding

\begin{tabular}{|l|l|}
\hline Sample & Code Name \\
\hline $5 \%$ Additive & A-1 \\
\hline $4 \%$ Additive & B-3 \\
\hline $3 \%$ Additive & C-2 \\
\hline $2 \%$ Additive & D-4 \\
\hline $5 \%$ Potassium Soap Of long chain Fatty Acids & E-5 \\
\hline No Additive & F-6 \\
\hline
\end{tabular}

\section{Results}


Field test for ants: Ants leave pheromones after them and it helps them find their way back to the nest. Calcium carbonate interferes with the navigational system of ant and prevents them from following pheromone trail left behind earlier. The necessary oils get absorbed by smell receptors. These receptors are located in the ant's nose and smells head towards brain's limbic system. It is this part of the ant's body that controls all the movements of the ant through mood, memory, emotions etc. Thus, the oils used keep the ants away from the coatings.

Graph 1 describes the results of ant's repellency test as sample A1 with 20\% Additive shows the best results at which only one ant appears in 20 minutes. B3 shows good resistance better than $\mathrm{C} 2$ but less effective than $\mathrm{A} 1$ as there were 3 ants in starting after 5 minutes at $\mathrm{C} 2$ while there was not a single ant at B3. After 20 minutes only 3 ants come at B3 and counting at C2 was 13 . Gradually D4 is better than F6 and E5 as contain only 2\% additive. At E5 initially observed more ants than F6 but with passing time ants preferred to move from that coating, in case of F6 inverse case of E5 is observed.

Cage test for Flies: The Eugenoloil, used, has natural Permethrin, proving best as flies repellant. Fig 3 describes the results of non-biting flies test performed in a glass Squair and note the landing flies on coated surface after different time intervals, we found that there was only $1 \mathrm{fly}$ land on A1 formula coated surface in 10 minutes and only 2 flies in 20 minutes. All others formulas results are comparable as in initial five minutes there was 1 fly landed on B3, 2 flies on C2, 2 flies on D4, 4 flies on E5 and 3 flies on F6. After 10 minutes the counting was 3,3,4 \& 4 flies simultaneously. Sample A1 resist better thanall other samples due to presence of higher concentration of Eugenol.

Cage test for Mosquitoes: Mosquitoes have acute receptors on their antennae, head etc. These receptors can direct the mosquitoes from one hundred feet distance. Scents are mainly responsible and helpful source for mosquitoes tempting them to prey. Citronella masks these scents which cause attraction for mosquitoes towards lactic acid, saccharides, carbon dioxide, blood etc. Higher concentration proves great repellence of mosquitoes as is shown in fig 4 only one Mosquito was landed after 20 minutes on A1. B3 and $\mathrm{C} 2$ resist against mosquitoes better than $\mathrm{E} 5$ and $\mathrm{F} 6$.

\section{Black Field Ants:}

Black field ants (Carpenter ants) are also tested on coated plates and found only 1 Black field ant at start but it also leaves the surface in 15 minutes and did not come back even after 20 minutes, while B3, C2 and D4 also resist better one reason is of such good results is also that all these coated plates are tested with comparison of F6 (Blank) so Black field ant prefer to be at F6 than any other because all other have some amount of repellent additive.

\section{Scrub Resistance}

Figure shows the application of manufactured paint at standard black scrub sheet with $200 \mu \mathrm{m}$ Film applicator as per Standard ASTM D4213 \& 2486. The concentrated paints with VOC may cause loss of scrub resistance. There are different scrub tests for varying paint products identified to be conventional 
interior paints. The convention interior paints can manage to resist upto 16 scrubs and the exterior paint can go good against upto 4000 scrubs with only a little loss of gloss.

The concentrated paints with VOC may cause loss of scrub resistance. There are different scrub tests for varying paint products identified to be conventional interior paints. The convention interior paints can manage to resist upto 16 scrubs and the exterior paint can go good against upto 4000 scrubs with only a little loss of gloss. The concentrated paints with VOC may cause loss of scrub resistance. There are different scrub tests for varying paint products identified to be conventional interior paints. The convention interior paints can manage to resist upto 16 scrubs and the exterior paint can go good against upto 4000 scrubs with only a little loss of gloss.

Table.6 Results of Washability of Paint Samples

\begin{tabular}{|c|c|c|c|c|c|c|c|c|}
\hline & Paint & $\begin{array}{c}\text { Manufactured } \\
\text { on }\end{array}$ & $\begin{array}{c}200 \mu \mathrm{m} \text { film } \\
\text { applied on } \\
\text { Black } \\
\text { Sheets }\end{array}$ & $\begin{array}{c}\text { Scrubs } \\
\text { Checked on } \\
\text { Scrub Tester } \\
\text { Machine }\end{array}$ & $\begin{array}{c}\text { Weight of } \\
\text { Sheet } \\
\text { Before } \\
\text { Scrubs (g) }\end{array}$ & $\begin{array}{c}\text { Weight of } \\
\text { Sheet } \\
\text { After } \\
\text { Scrubs (g) }\end{array}$ & $\begin{array}{c}\text { Difference } \\
\text { in Weight } \\
\text { (g) }\end{array}$ & Scrubs \\
\hline 1 & A-1 & $23 / 3 / 2018$ & $27 / 4 / 2018$ & $29 / 4 / 2018$ & 30.002 & 28.637 & 1.365 & $\mathbf{1 8 - 2 4}$ \\
\hline 2 & B-3 & $23 / 3 / 2018$ & $27 / 4 / 2018$ & $29 / 4 / 2018$ & 30.008 & 28.712 & 1.296 & $\mathbf{1 7 - 2 4}$ \\
\hline 3 & C-2 & $23 / 3 / 2018$ & $27 / 4 / 2018$ & $29 / 4 / 2018$ & 30.006 & 28.740 & 1.266 & $\mathbf{1 8 - 2 4}$ \\
\hline 4 & D-4 & $23 / 3 / 2018$ & $27 / 4 / 2018$ & $29 / 4 / 2018$ & 30.001 & 28.734 & 1.267 & $\mathbf{1 7 - 2 4}$ \\
\hline 5 & E-5 & $23 / 3 / 2018$ & $27 / 4 / 2018$ & $29 / 4 / 2018$ & 30.003 & 28.742 & 1.261 & $\mathbf{1 5 - 2 4}$ \\
\hline 6 & F-6 & $23 / 3 / 2018$ & $27 / 4 / 2018$ & $29 / 4 / 2018$ & 30.002 & 28.745 & 1.257 & $\mathbf{1 9 - 2 4}$ \\
\hline
\end{tabular}

Result of these scrubs sheets are above in table; it is observed that even with $5 \%$ Additive its Scrubs are in limits as film starts rupturing at $18^{\text {th }}$ scrub and completely tor at $24^{\text {th }}$ scrubs. So, all other sheets are checked for 24 scrubs. The difference in weight loss is comparable.

\section{MFFT of Binder}

Higher MFFT causes hardness of the polymer and there will be less of thermoplastic polymer. Thus, there is least chance for the dust particles to land, adhere and stay on the paint film. Increased amount of dust accumulation causes attraction for the insects onto the paint film and vice versa meaning less accumulation of dirt saves paint surface from insects. Binder was tested on Rohpoint Minimum Film Forming Temperature machine and found the $5.9^{\bullet} \mathrm{C}$.

\section{Conclusion}

By all experimental study, found that the paint having additive based on potassium salt of long chain fatty acid \& blend of citronella oil along with four other abovementioned oils has successfully worked as 
repellent of pavement ants, non-biting Flies, mosquitoes and black field ant with $80 \%$ efficiency. It is envisioned that the formulated paint is effectively function as insect repellent thus as an alternative way to reduce the insect-borne diseases. The $15 \%$ additive containing paint formulation has the best condition by giving good adhesion and $80 \%$ effective insect repelling time.

\section{Declarations}

\section{Ethical Approval and consent to participation:}

Not applicable

\section{Consent for publication}

Not applicable

\section{Availability of data and material}

Data is available on request

Competing interests The authors have no competing interests.

\section{Funding}

The authors received no specific funding for this work.

Authors' contributions Zeeshan Ahmad: Formulation of Additive \& Emulsion Paint has been developed by Zeeshan Ahmad.

Faiza Hassan: Supervise the research and all related materials are arranged by Faiza Hassan.

Sana Noor: Optimization of additive dosage in paint has been done by Sana Noor.

Munir Ahmad: All Testing's are suggested and designed.

Khalid Rashid: Testing's are conducted and results are noted by Khalid Rashid.

\section{Acknowledgements}

I would like to thank and sincerely acknowledge the help of supervisor Dr. Faiza Hassan, Coordinator Department of Chemistry, University of Lahore, her continuous and consistent guidance, support and encouragement gave us a real motivation in doing this project.

\section{References}

[1] Vector control research centre, edited by Rajagopalan (Misc Publ 11, Pondicherry) 1989 
[2]M. Tracy, H. Jason, and A. Adelaide, "Insect repellents: Historical perspectives and new developments," J Am Acad Dermatol, vol. 2008;58, pp. 865-871, 2008

[3] Heick HMC, Shipman RT, Norman MG, James W. Reyelike syndrome associated with use of an insect repellent in a presumed heterozygote for ornithine carbamyl transferase deficiency. J Pediatr 1980;97:471-3.

[4] Isman 2000, 2004; Isman \& Machial, 2006)

[5] Pavela R, Benelli G (2016) Essential oils as eco-friendly biopesticides? Challenges and constraints. Trends Plant Sci 21:1000-1007

[6] Morgans, W.M., “Outlines of paint technology," third ed. Griffin: London, 1990.

[7] Brock, T., Groteklaes, M., \&Mischke, P., "European Coatings Handbook," 2nd ed. Lamspringe, Germany: Quensen Druck, 2010.

[8] Goldschmidt, A., and Streitberger, H.-J., "BASF Handbook on Basics of Coating Technology," Paderborn, Germany: Bonifatius GmbH, 2007.

(9) Paint and Surface Coatings (Second edition)Theory and PracticeWoodhead Publishing Series in Metals and Surface Engineering1999, Pages 1-18, doi.org/10.1533/9781855737006.1

\section{Graphs}

Graphs 1-4 can be found in the Supplemental Files.

\section{Figures}

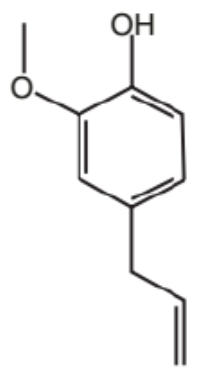

Eugenol

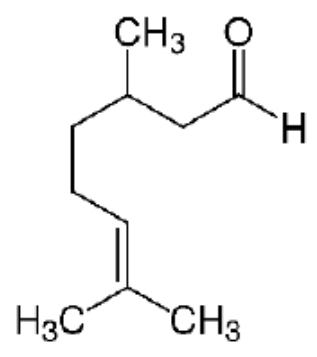

Citronella

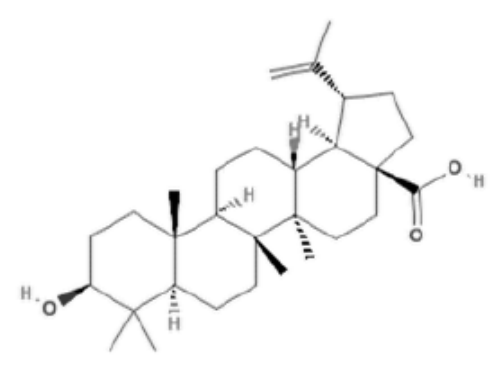

Rosmarinus officinalis

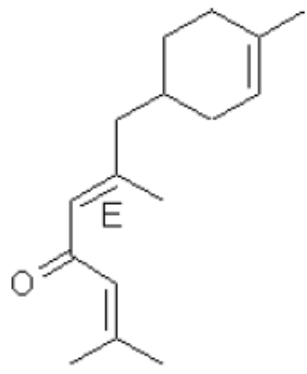

Cedrus

\section{Figure 1}

Chemical Structures of Essential Oil 


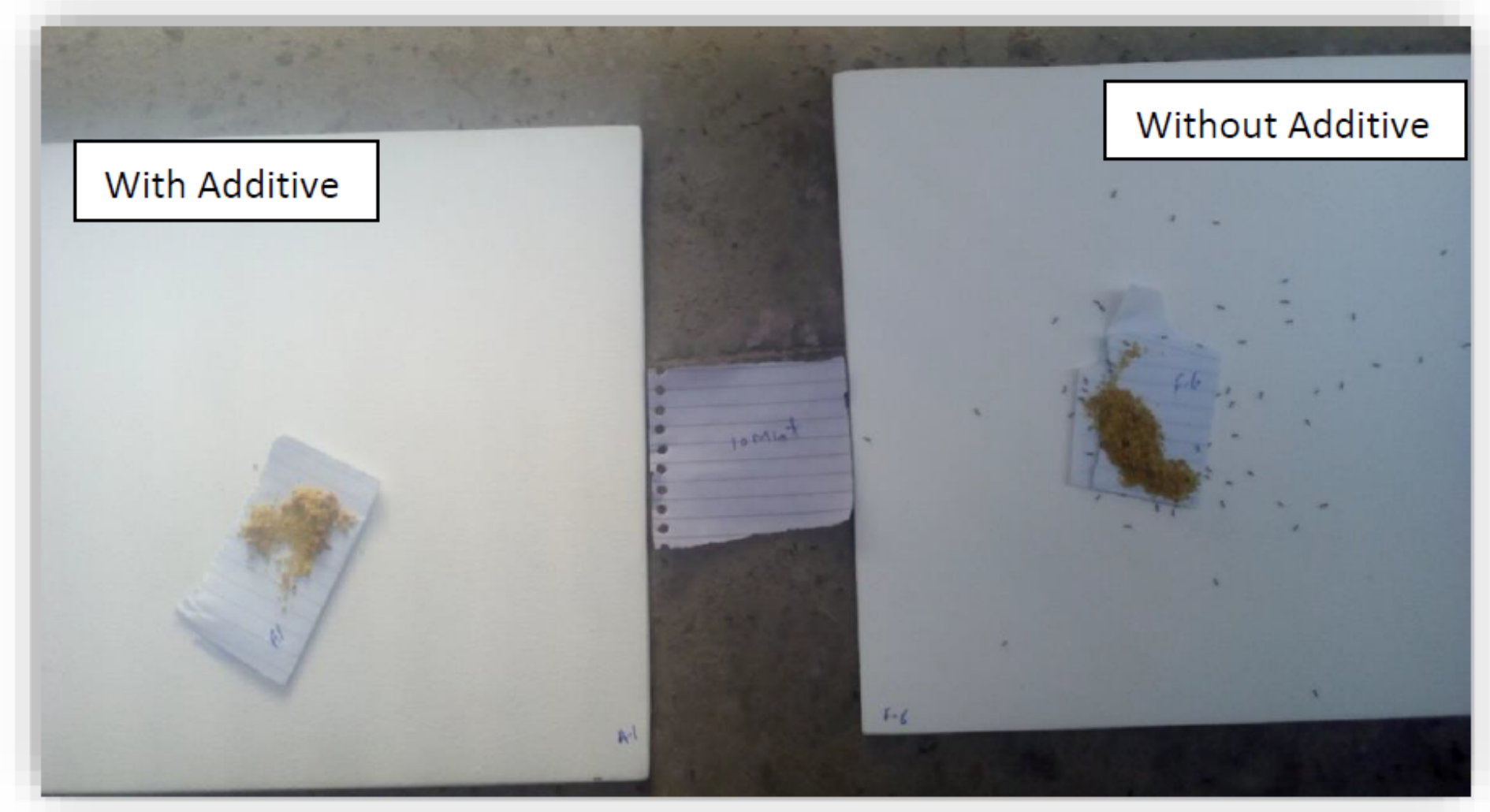

\section{Figure 2}

Ants Repellency on Coated Sheets

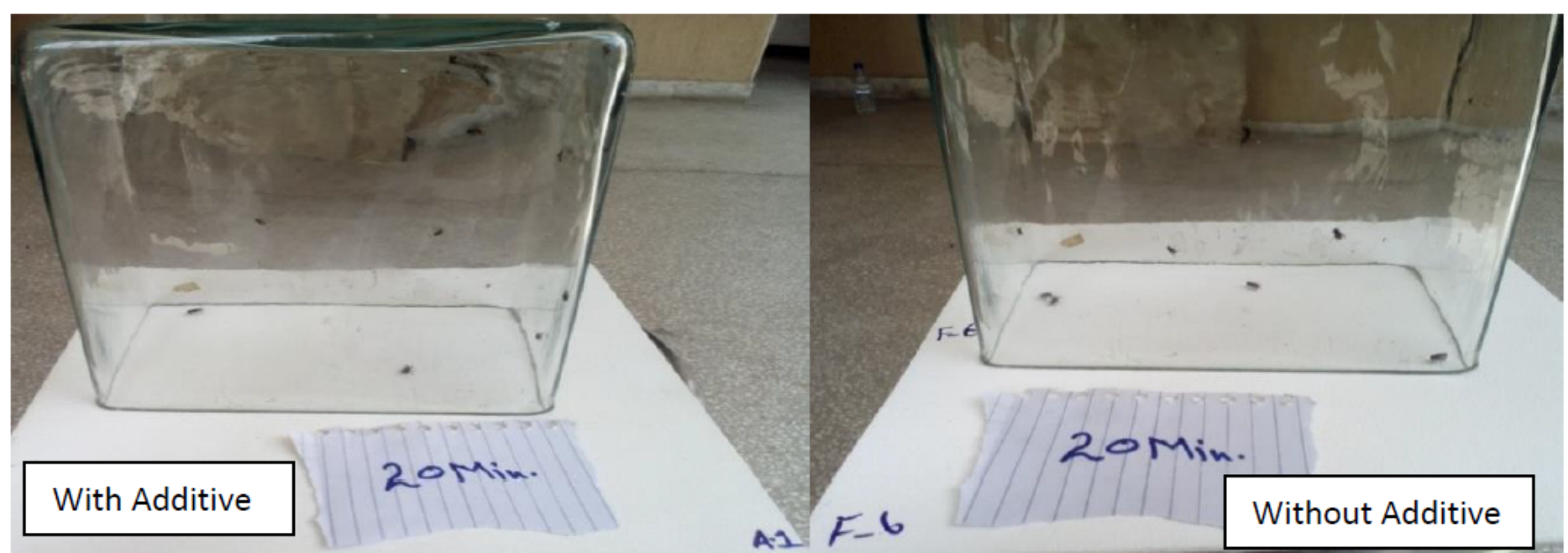

Figure 3

House hold Flies test 


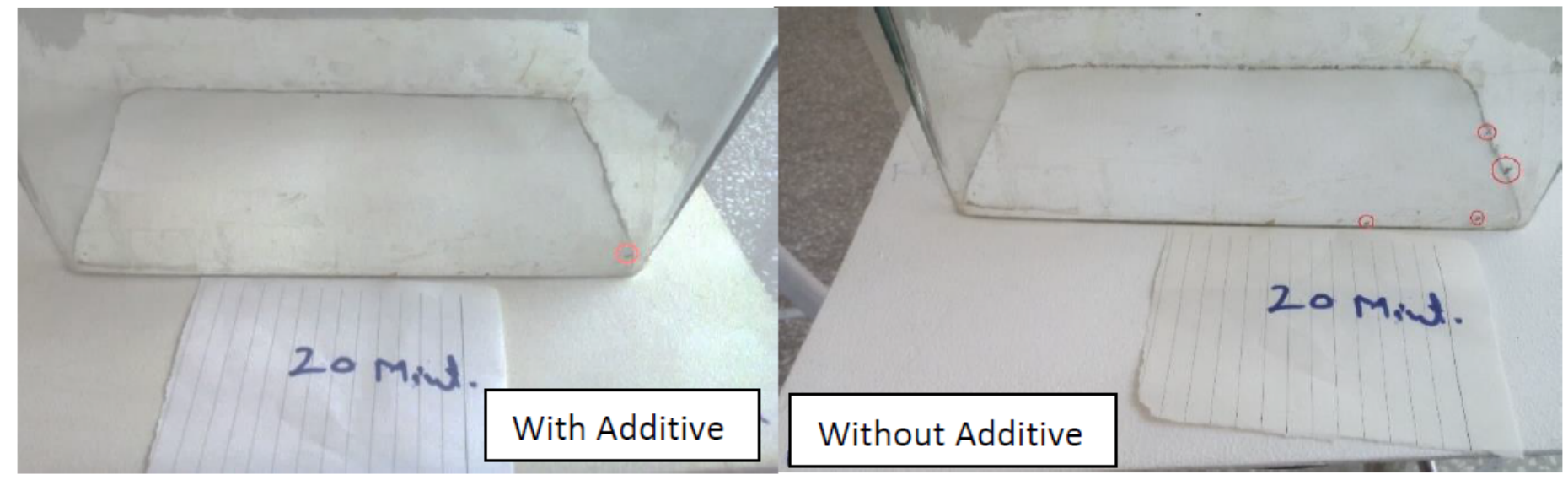

Figure 4

Mosquitoes Cage Test

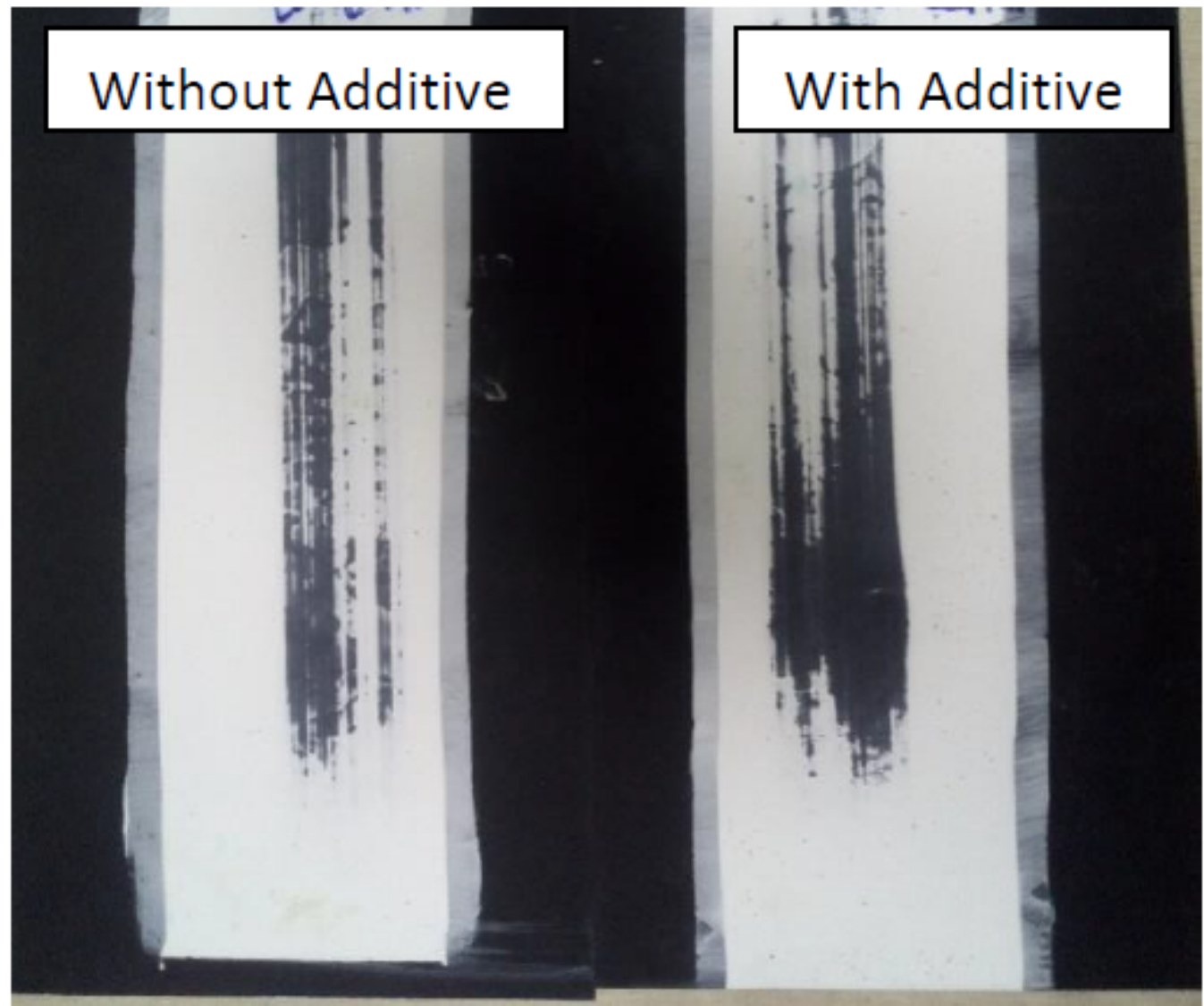

Figure 5

Sheets after Scrub Testing 


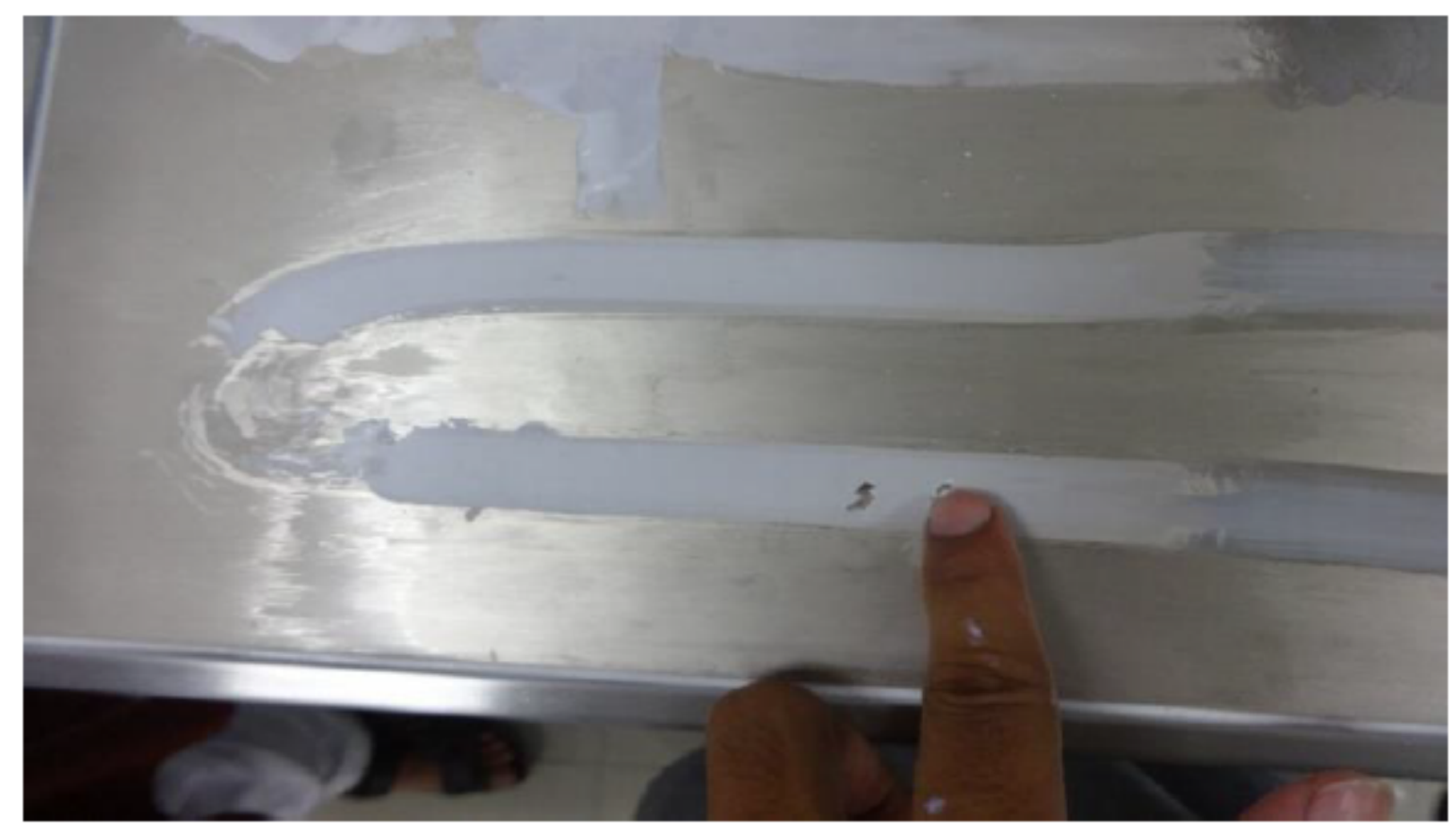

Figure 6

Film Formation (second figure 5 in the manuscript.)

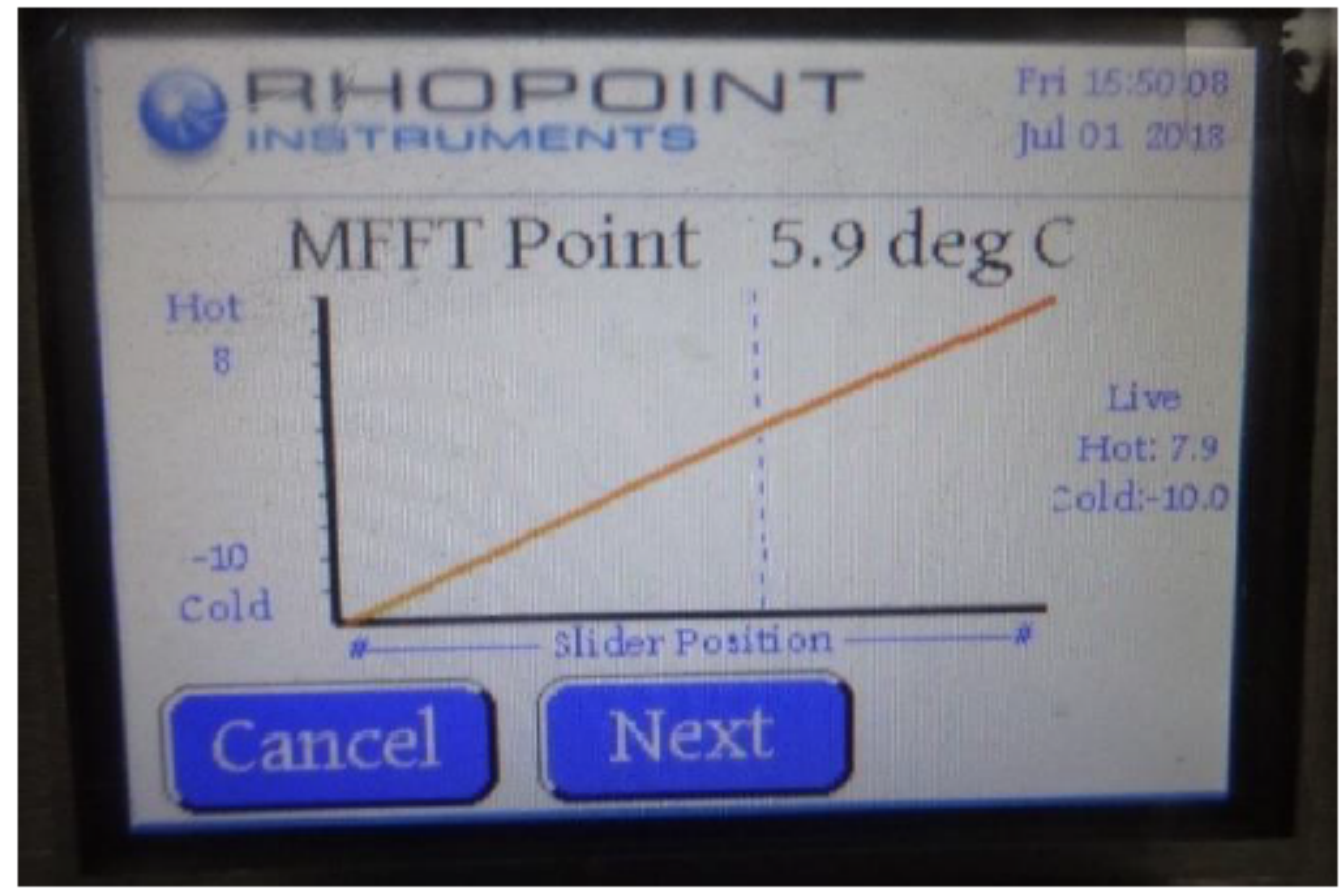

Figure 7

MFFT Temperature

\section{Supplementary Files}


This is a list of supplementary files associated with this preprint. Click to download.

- Graph1.png

- Graph2.png

- Graph3.png

- Graph4.png

- GraphicalAbstract.docx 